Journal of Mechanical, Civil and Industrial Engineering

ISSN: $2710-1436$

DOI: $10.32996 / j m c i e$

Journal Homepage: www.al-kindipublisher.com/index.php/jmcie

\title{
Analysis of Business Strategy of PT. XXX Using the Space Matrix Model
}

\author{
Imbuh Rochmad 1 8D and Isdaryanto Iskandar ${ }^{2}$ 8(D), \\ ${ }^{12}$ Faculty of Engineering, Atma Jaya Catholic University of Indonesia, Indonesia
}

$\triangle$ Corresponding Author: Imbuh Rochmad, E-mail: imb_rochmad@yahoo.co.id

\section{ARTICLE INFORMATION ABSTRACT}

Received: August 08, 2021

Accepted: October 03, 2021

Volume: 2

Issue: 2

DOI: 10.32996/jmcie.2021.2.2.2

\section{KEYWORDS}

Market leader, SPACE Matrix, strategic position, business viability, strategy recommendation
PT. XXX is one of the pioneers and market leaders of building materials companies in Indonesia. Looking at the performance over the last five years PT. XXX is experiencing a decline in production capacity, although judging from the market share its products are still quite attractive to customers. This means that PT. XXX failed to grow its business even in an effort to maintain it, while the building materials industry continued to grow. The problem is how this can happen and what steps a company must take to return its business conditions for the better. The purpose of this study is to get an overview of the strategic aspects of the company with the SPACE Matrix Model and its dimensions including; financial strength, competitive advantage, industrial-strength, and environmental stability. By calculating the average value of each aspect, then the result is used to determine the position of PT. XXX in the SPACE Matrix. Based on the results of the study, the strategic position of PT. XXX is in the Competitive Quadrant. Therefore, the recommended strategy is integration strategy, intensive strategy, or collaboration (joint venture). By using the recommended strategy, it is hoped that PT.XXX will be able to restore its business viability and return to being the market leader in building materials products.

\section{Introduction}

The current era of globalization is making the competition in the business world very tight, one of them is the building materials industry. This is marked by the influx of various product brands circulating in the national market, sourced from local manufacturers and outside of the country. In such a situation, the main thing that these business actors must do to grow and survive is to implement the right business strategy and provide satisfaction and added value to consumers.

There is no denying that the main determinants of consumer satisfaction are product or service quality and service quality. Organizations or companies that can provide quality products and services better than others will be in demand by consumers. As one of the building materials companies in Indonesia, PT. XXX is committed to constantly improving competitiveness and seizing greater market share, therefore demanding an increase in the quality of products and services as a determining factor of consumer satisfaction. Figure 1 below is a market perspective from the five big of building materials industry where PT. XXX is indicated by the notation "B".

\section{K C AL-KINDI CENTER R D FOR RESEARCH AND} Your goteway to world-class research

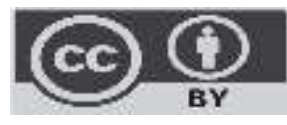

Published by Al-Kindi Center for Research and Development. Copyright (c) the author(s). This open access article is distributed under a Creative Commons Attribution (CC-BY) 4.0 license 


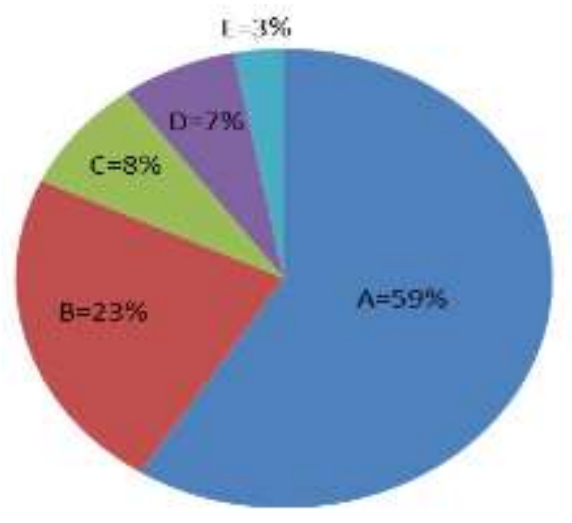

Fig. 1 Market Share Perspective of Building Materials Industry.

Based on its market share, building materials produced by PT. XXX still shows that these products are still in demand by customers, but judging from the company's performance in Figure 2 over the past few years, PT. XXX is experiencing a decline in performance, its production capacity decreasing from year to year.

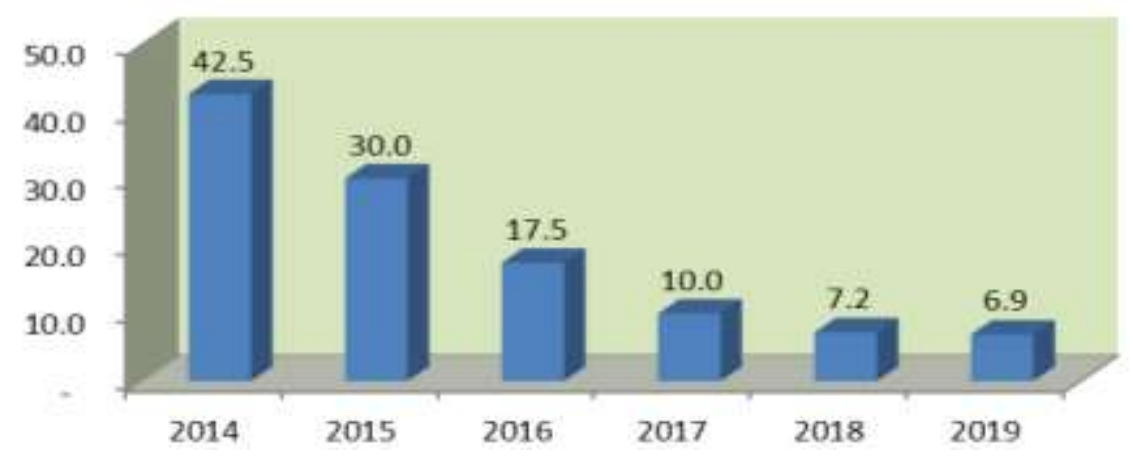

Fig. 2 Production Capacity PT. XXX (in million sheets).

The purpose of this study is to get an overview of the strategic aspects of the company with the SPACE Matrix Model and its dimensions, among others; financial strength, competitive advantage, industrial-strength, and environmental stability to get an overview of the company's strategic position. By using the recommended strategies, it is hoped that PT.XXX can return to the continuity of its business and return to being the market leader for building material products.

\section{Theoretical Review}

\subsection{Space Matrix Model}

The Position Strategy and Action Evaluation Matrix (SPACE) model or the Position Strategy and Action Evaluation matrix were proposed and developed by Alan Rowe, Richard Mason, Karl Dickel, Richard Mann, and Robert Mockler in 1994 (Rowe et al., 1994) [23]. Rowe et al. try to overcome some limitations/shortcomings of the methods/tools mentioned above. Based on the explanation by Rowe et al, $(1994 ; 255)$, the SPACE matrix is a tool/method to map the condition of the company in the quadrant matrix with the aim that the company can see its position so can determine the appropriate strategic posture for further expansion [23]. Based on the strategy vector in the SPACE matrix, it can show normatively the strategy that should be carried out by the company. Basically, the SPACE diagram can be seen as a brief overview of the Profit Impact of Market Strategy (PIMS) approach, as each dimension is a combination of several factors evaluated separately. By incorporating a number of factors, companies can test a number of alternative strategies from a variety of perspectives, where these will place the right strategy (Rowe et al., 1994, p. 255) [23].

According to Rowe, et al. (1994; 258) financial strength (FS) and competitive advantage (CA) as internal dimensions are two determinant keys of a company's strategic position. Meanwhile, industrial-strength (IS) and environmental stability (ES) as external dimensions characterize the strategic position of the whole industry. Financial strength becomes especially important when there 
are adverse economic conditions, such as rising inflation rates or high-interest rates. Companies with strong financial strength will be in a good position to diversify into more attractive industries or perform aggressive movements in current industries to replace the weak competitors. Companies that enjoy advantages over competitors in various aspects, namely market share, cost, or technology usually have the ability to maintain higher profit margins as well. This competitive advantage is usually a very important factor in the face of a declining market, that is when companies with profits are not maximized and it is very difficult to survive (Rowe et al., 1994) [23].

In emerging markets, financial strength and operational strength help maintain or increase momentum and even marginal competitors can find markets in these circumstances. As the market slowly rises, the competitive conditions in the industry worsen, and companies really need specific measures to protect their competitive position. Therefore, industrial-strength can enhance a company's competitive position (Rowe et al., 1994, p. 258) [23].

Each strategy that will be obtained in the SPACE chart consists of four dimensions of input. The quadrant matrix consists of 4 (four) axis where separate the line and also represents several company factors, namely:

1. Financial Strength (FS), $y+$ axis

The items included in this FS are everything related to the company's finances. Return Of Assets (ROA), efforts to improve business, company liquidity, and cash flow are included in these financial strength factors (Gurbuz, 2013) [14]. Variables in this factor will be rated in the form of numbers 1 to 6 . Number 1 indicates the worst, while number 6 indicates the best.

2. $E S=$ Environmental Stability, $y$-axis

ES shows the stability of companies in the industry. Variables included in this category include inflation rates, government policies on products, demand differences, and tax elements (Gurbuz, 2013) [14]. Variables will be rated with numbers -1 to -6 . The number -1 indicates the best while -6 is the worst.

3. IS = Industrial Strength, $x+$ axis

The variables included in IS are variables derived from external companies. The variables included in IS include barriers to entry into the building materials business, growth potential in the building materials business, ease of access to financing, and availability/knowledge of technology (Gurbuz, 2013) [14]. These variables will also be scored with numbers 1 to 6 .

4. $C A=$ Competitive Advantage, $x$ - axis

Competitive advantages can be in the form of market share, product quality, product life cycle, and product brand image (Gurbuz, 2013) [14]. The same with ES, variables in CA will also be rated between -1 to -6.

The four dimensions will determine the strategic posture of the company to be achieved, namely aggressive, competitive, conservative, or defensive (Radder \& Louw, 1998) [21] (Rumanti \& Syauta, 2013)[24]. This posture then is translated into generic competition strategies, which will assist the company in projecting appropriate strategies for company sustainability, namely: overall cost leadership, differentiation, focus, or defense (Rowe et al., 1994, p. 258) [23]. Strategy determination analysis using SPACE is based on the logic that maximizes the company's strengths and opportunities, but at the same time can reduce the company's weaknesses and threats.

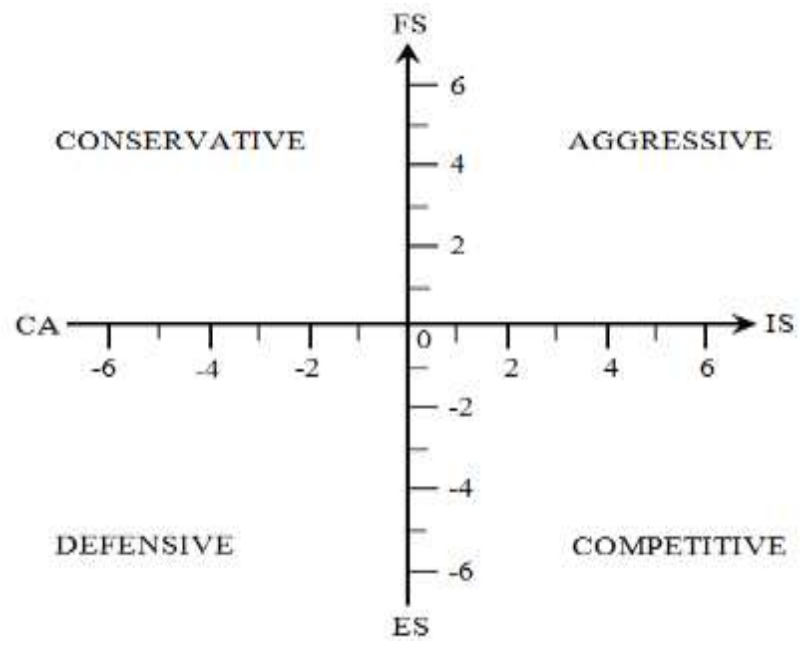

Fig. 3 Strategy Posture Quadrant 
1. Aggressive Posture An aggressive posture is a suitable style for an industry with an attractive type of competition with a bit of environmental clutter. This is a very profitable situation, the company has the opportunity and strength to be able to take advantage of the opportunities available. The strategy that must be applied in this situation is to support aggressive growth policies (Silaban $\&$ Syah, 2018) [25].

2. Competitive Posture

In this competitive posture, the industry is still in the attractive category, the company feels comfortable with its competitive advantage even in an unstable environment. A critical factor in this posture is financial strength. Companies in this situation need more financial resources to maintain their competitive advantage (Silaban \& Syah, 2018) [25].

3. Conservative Posture

This conservative posture is an industry with a stable market type, but with low growth. The company's focus is directed at how to build financial stability, with the critical factor being product competitiveness, by cutting product lines. Reduce costs by focusing on increasing cash flow, protecting product competitiveness, developing new products, and trying the lucky at entering attractive (Silaban \& Syah, 2018) [25].

4. Defensive Posture

In this posture is an industry with an unattractive type where the company's products do not have a competitive advantage and do not have good financial strength. What a company should do is prepare itself to withdraw from the market, stop unprofitable products, aggressively reduce costs, reduce unused capacity and reduce or delay investment (Silaban \& Syah, 2018) [25].

Each company in a different quadrant position has different strategy choice suggestions. The following is a selection of strategies for each quadrant (David et al., 2017) [8] (Silaban \& Syah, 2018) [25]:

- Aggressive Quadrant: Integration Strategy, Intensive or Diversification.

- Competitive Quadrant: Integration Strategy, Intensive or Joint Venture.

- Conservative Quadrant: Intensive Strategy or Concentric Diversification.

- Defensive Quadrant: Defensive Strategy or Concentric Diversification.

\subsection{Strategy Definition}

Strategy is a tool to achieve long-term goals. Fred R. D.; Silaban, B. E., \& Firaidie, P. R., 2008 (David et al., 2017) [8] (Silaban \& Syah, 2018) [25]. Pearce \& Robinson; Silaban, B. E., \& Firaidie, P. R., 2008 (Silaban \& Syah, 2018) [25], states that strategy is a company's game plan that reflects a company's awareness of how, when, and where to compete, with whom to compete, and for what purpose or target the company is competing with.

Types of Strategies

Fred R. D., 2006; Silaban, B. E., \& Firaidie, P. R., 2008 (David et al., 2017) [8] (Silaban \& Syah, 2018) [25], classifies the following strategies:

1. Integration Strategy: includes forward integration, backward integration, and horizontal integration.

2. Intensive Strategy: includes market penetration, market development, and product development.

3. Diversification Strategy: includes concentric diversification, horizontal diversification, and conglomerate diversification.

4. Defensive Strategy: includes savings/downsizing, sales, and liquidation.

5. Joint Venture \& Combination Strategy.

6. Mergers and Acquisitions.

1. Integration Strategy

Forward Integration

This strategy is implemented with the aim of acquiring ownership or increasing control over distributors or retailers (Tellis, 1989) [26].

\subsection{Backward Integration}

This strategy aims to seek ownership or control over the supplier company. This strategy is particularly suitable when supplier companies are currently unreliable, overpriced, or unable to meet company needs (Tellis, 1989) [26]. 
1. Horizontal Integration

Seek ownership or increase control over competing companies (Tellis, 1989) [26].

2. Intensive Strategy

Market Penetration

Find a larger market share for an existing product or service by doing more powerful marketing (Tellis, 1989) [26].

Market Development

Introduce existing products or services to new geographical areas. The climate for international market expansion is improving (Tellis, 1989) [26].

Product Development

Seek increased sales by improving and changing the appearance of existing products or services or developing new ones. Product development usually requires large expenditures for research and development (Tellis, 1989) [26].

3. Diversification Strategy

Concentric Diversification

Adding new products or services but still extensively relevant. Whereby focusing on features that have provided its own competencies to the company, the company uses this strength in diversifying.

\section{Horizontal Diversification}

Adding new products or services that are not related to existing customers. This strategy risk is not as big as conglomerate diversification, as companies must already know the characteristics of existing customers.

Conglomerate Diversification

Adding new products or services that are not related to the old ones. Several companies conglomerate diversification based in part on profit expectations by dividing companies that buy and sell part by part.

4. Defensive Strategy

Savings/Reduction

Regroup through cost savings and assets to increase or increase sales and decrease profits. During the savings process, management works with limited resources and faces pressure from shareholders, employees, and the media. Savings may require the sale of land and buildings to increase needed cash, reduce production lines, close marginal businesses, close obsolete factories, regulate automated processes, reduce the number of employees, and roll out cost control systems.

Devastation

Selling a division of an organization or company in an effort to raise capital for further strategic acquisition or investment. Devastation can be part of a comprehensive mitigation strategy to eliminate unprofitable business organizations, require large amounts of capital, or be incompatible with other corporate activities.

Liquidation

Selling all the assets of the company part by part, at the value of these tangible assets is called liquidation. Liquidation is the acknowledgment of defeat and the result can be an emotionally difficult strategy. But it is better to take this road than to continue to suffer huge losses.

5. Joint Ventures and Combination

Joint Venture

Two or more sponsoring companies form separate organizations with the aim of establishing mutually beneficial cooperation.

Combination Strategy

Organizations try a combination of two or more strategies simultaneously, but a combination strategy can carry special risks if done too far. 


\section{Mergers and Acquisitions}

Mergers and acquisitions are two ways widely used of implementing strategy. Acquisition occurs when a large organization or company buys a smaller company or otherwise. Mergers occur when two organizations or companies of the same size and elements are combined to form one company.

\subsection{Strategy Planning}

The definition of strategic planning excerpts from Duncan's statement, 1966, is a series of processes within the organization to understand the situation and guide decision-making for the organization. Kotler, P., 2003, says that strategic planning is a managerial process, developing and maintaining strategic direction, adapted to ever-changing marketing opportunities, so as to suit the goals and resources of the organization. Wheelan and Hunger, 1996, strategic planning is the development of long-term plans for effective management of environmental opportunities and threats, seen from the strengths and weaknesses of the company) (Silaban \& Syah, 2018) [25].

\subsection{Strategy Management}

Strategy management is defined differently by several experts. According to Fred R. D., 2006, strategy management is the art and knowledge of formulating, implementing, and evaluating multifunctional decisions that enable organizations to achieve their goals. According to Pearce and Robinson, 2000, states that management strategies are a series of decisions and actions realized in the formulation and implementation of plans designed to achieve corporate goals. Wheelan and Hunger, 2000, management strategy is a series of decisions and actions of managerial that determine a company's long-term performance (David et al., 2017) [8] (Silaban \& Syah, 2018) [25].

\subsection{Steps of Strategy Management}

Fred R. D., 2006; Silaban, B. E., \& Firaidie, P. R., 2008, divides the steps of strategic management into three, namely: strategy formulation, strategy implementation, and strategy evaluation (David et al., 2017) [8] (Silaban \& Syah, 2018) [25].

\subsubsection{Strategy Formulation}

Strategy formulation includes developing the vision and mission of the organization, identifying organizational opportunities and threats, determining strengths and weaknesses, determining long-term goals, determining alternative strategies, and choosing a strategy to implement.

\subsubsection{Strategy Implementation}

The implementation consists of annual objectives, completing policies, motivating employees, and allocating resources so that the strategies formulated can be implemented. Successful strategy formulation does not guarantee successful strategy implementation. It is always more difficult to do something (strategy implementation) than we formulate it (strategy formulation).

\subsubsection{Strategy Evaluation}

Is the final stage of strategy management? Company leaders need to know when a particular strategy is not working well, strategy evaluation is primarily an attempt to obtain this information. All strategies can be modified in the future as external and internal factors are constantly changing. The three basic types of activities to evaluate a strategy are:

1. Examine external and internal factors that form the basis of the current strategy.

2. Measure achievement.

3. Take corrective action.

\section{Research Methodology}

\subsection{Research Design}

This study is a descriptive study to get an overview of the strategic position analysis of PT. XXX judged in the four dimensions of the SPACE matrix, then formulates the most appropriate strategy for the company to improve performance and maintain business continuity.

\subsection{Types and Techniques of Data Collection}

Data collection for the purpose of this study was done in two ways, divided into primary data and secondary data (Farajian et al., 2019).

\section{Primary Data}


Namely the data obtained from field observations, interviews with related parties at PT. XXX, and spreads questionnaire to obtain an overview of organizational management covering four aspects, among others; financial strength, competitive advantage, industrial-strength, and environmental stability.

\section{Secondary Data}

Data were obtained from various sources of information such as literature review and data from the company.

\section{Analysis and Discussion}

\subsection{Strategy Analysis with SPACE Matrix}

Space Matrix describes two internal dimensions, namely financial strength and competitive advantage, and two external dimensions, namely industrial strength and environmental stability. Based on the analysis of data obtained from primary and secondary data, the following findings are presented one by one on each dimension of the SPACE matrix.

\subsection{Financial Strength Analysis}

Judged from the ratio of income to bad assets for a period of five years, based on the average value of the questionnaire, Return of Assets (ROA) received a rating of 3.333. Efforts to increase business growth done in recent years have not shown a significant impact, it scores 3.133. The settlement of short-term liabilities (liquidity), especially for the payment of bills to suppliers, has not been fully implemented, for this reason, it has received a rating of 3.300. Based on the above indicators, it can be seen that the company's cash flow is not so good that it has got a rating of 2.533 .

\subsection{Competitive Advantage Analysis}

Seen from the perspective of the building materials industry, the superiority of PT. XXX still has loyal customers around $23 \%$ of the top five players with this rating for a market share of -3.167 . Good market share is of course supported by good product quality, PT. XXX has implemented the ISO 9001: 2015 and SNI quality management system, so the product quality rating is -3.567 . The product life cycle is long enough to be supported by the quality of the product itself, however, because Indonesia is very large, the product life cycle rating is -3.333 . Customer loyalty is strongly influenced by the product brand image because of the product brand PT. XXX has long been in the hearts of customers, so a market share is still promising. The rating for the brand image is 3.400 .

\subsection{Environmental Stability Analysis}

Uncontrolled inflation rates have had a significant impact on the growth of the industrial world, especially the building materials industry, but in the last five years, the inflation rate has been relatively stable and still considered mild inflation, the rating for inflation is -3.433 . Government policies that still provide flexibility for building materials manufacturers to grow and develop, the level for this is -3.567 . Variability in product demand greatly affects the company's performance, because of PT. XXX is equipped with the convenience of being able to adapt to various demands, so this will not be a significant problem, rating -3.100 . The tax by the government applies equally to all business actors in the building materials business even its value affects the selling price, the rating for tax is -4.100 .

Table 1. Inflation Rate

\begin{tabular}{lllll}
\hline \multicolumn{4}{l}{ Inflation Rate } \\
\hline 2015 & 2016 & 2017 & 2018 & 2019 \\
$6.38 \%$ & $3.53 \%$ & $3.81 \%$ & $3.20 \%$ & $2.81 \%$ \\
\hline
\end{tabular}

Industrial Strength Analysis

The barrier to entering the building materials industry is quite large because it needs to have mastery of technology to choose the type of machine available so that it can give optimal results, so it is given a rating of 3.467. The business growth potential of these building material products is still quite good, this can be seen from the increase in the number of similar product industries, the rating is 3.500. No matter how good the industrial strength is, but if not supported by good financial strength, ease of access to financing for business development is also less pleasant, judging from the financial capability and level of difficulty in obtaining loans, this rating is 3.400 . The availability of technology to adapt capacity and improve quality at this time is very different, companies can choose according to the targets to be achieved and adapted to their financial capabilities. With the latest available technology, it has a rating of 3.767 . 


\begin{tabular}{|c|c|c|c|c|c|}
\hline \multicolumn{3}{|c|}{$\begin{array}{l}\text { INTERNAL FACTORS } \\
\text { Financial Strength (FS) }\end{array}$} & \multicolumn{3}{|c|}{$\begin{array}{l}\text { EXTERNAL FACTORS } \\
\text { Environmental Stability (ES) }\end{array}$} \\
\hline No. & Aspects & Rating & No. & Aspects & Rating \\
\hline 1 & Return of Assets (ROA) & 3.333 & 1 & Rate of Inflation (I) & -3.433 \\
\hline 2 & Leverage (LV) & 3.133 & 2 & Government Policy (GP) & -3.567 \\
\hline 3 & Liquidity (LQ) & 3.300 & 3 & Demand Variability (DV) & -3.100 \\
\hline 4 & Cash Flow (CF) & 2.533 & 4 & Taxation (TX) & -4.100 \\
\hline \multicolumn{2}{|c|}{ Average } & 3.075 & \multicolumn{2}{|c|}{ Average } & -3.550 \\
\hline \multicolumn{3}{|c|}{ Competitive Advantages (CA) } & \multicolumn{3}{|c|}{ Industrial Strength (IS) } \\
\hline No. & Aspects & Rating & No. & Aspects & Rating \\
\hline 1 & Market Share (MS) & -3.167 & 1 & Barriers to Entry (BE) & 3.467 \\
\hline 2 & Product Quality (PQ) & -3.567 & 2 & Growth Potential (GP) & 3.500 \\
\hline 3 & Product Life Cycle (PLC) & -3.333 & 3 & Access to Financing (AF) & 3.400 \\
\hline 4 & Brand Image (BI) & -3.400 & 4 & Technology (T) & 3.767 \\
\hline \multicolumn{2}{|c|}{ Average } & -3.367 & \multicolumn{2}{|c|}{ Average } & 3.533 \\
\hline
\end{tabular}

\subsection{Space Matrix PT. XXX}

After analyzing all the strategic factors of PT. XXX describes the internal strategic position which includes the dimensions of financial strength and competitive advantage and the external strategic position which includes the dimensions of environmental stability and industrial strength, including the rating argument for each factor, the following will seen the position of PT. XXX on the SPACE matrix.

Coordinates for $x$-axis $(C A+I S) \quad=-3.367+3.533=\mathbf{0 . 1 6 6}$

Coordinates for the $y$-axis $(F S+E S)=3.075+-3.550=\mathbf{- 0 . 4 7 5}$

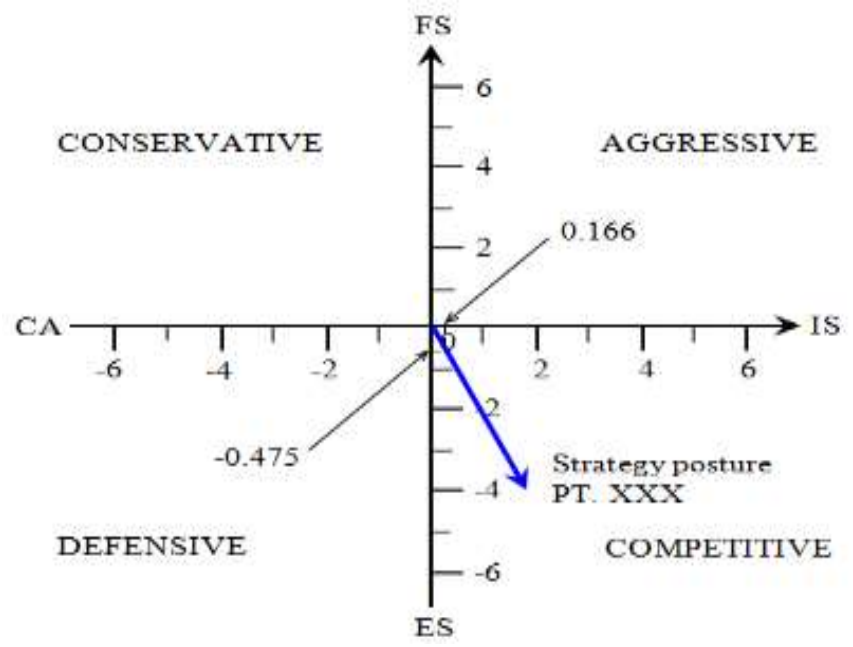

Fig. 4 Strategy Posture of PT. XXX

Based on Figure 4, it can be seen that the strategy vector direction of PT. XXX, which shows the company's position in the competitive quadrant. In accordance with the theory in the literature review, PT. XXX who are in the competitive quadrant can 
choose a competition strategy between integrative strategy and/or intensive strategy and/or joint ventures. Based on the integrative strategy, three forms of strategy description can be selected, namely; forward integration, backward integration, and horizontal integration. Meanwhile, in intensive strategy, three forms can also be selected, namely; market penetration, market expansion, and product expansion. However, based on the analysis of internal and external strategic factors that have been done by researchers combined with the results of an interview with the leader of PT. XXX about owned resources, researchers recommend selecting forward integration strategy and market penetration or collaboration (joint venture). Forward integration strategy can be done by make relationships with other companies to collaborate in the manufacture of products by maclon and collaborations in selling supporting products with other companies. This strategy can be combined with an intensive strategy with market penetration, which is to make more intensive marketing efforts to regain old and less loyal customers so that PT. XXX is expected to increase its market share.

\section{Conclusion}

From the results of data analysis and above discussions, conclusions can be made, among others: based on the analysis of the internal strategic position in this case the dimension of financial strength and the dimension of competitive advantage as well as the analysis of external strategy position, such as the dimension of environmental stability, industrial strength dimension, and PT position. PT.XXX in the SPACE matrix is in the competition quadrant; per the position of PT. XXX on the SPACE matrix and based on observations and interviews with the leadership of PT. XXX, the researchers recommend a combination strategy between future integration strategies and intensive strategies through market penetration or joint ventures. Therefore, it is hoped that PT. XXX will manage to regain its position as a market leader.

Based on the financial performance of PT. XXX which has tended to decline in the last few years, the research recommends PT. XXX currently to be more focused on the recovery of financial performance. This can be done by increasing revenue from various services while reducing inefficient operating costs. In implementing the strategy recommended above PT. XXX must do so at the lowest possible cost or the strategy to be implemented does not require a large investment.

Acknowledgments: We are thankful to "Faculty of Engineering, Atma Jaya Catholic University of Indonesia" for their support and necessary facilities to carry out this study.

Conflicts of Interest: We declare that we have no financial or personal relationships with other people or organizations that can influence our work.

\section{References}

[1] Benson, A. M., \& Henderson, S. (2005). Strategic characteristics of sport and recreation provision: an application of SPACE analysis. Managing Leisure, 10(4), 251-267.

[2] Betz, F. (2002). Strategic business models. Engineering management journal, 14(1), 21-28.

[3] Bharadwaj, S. G., Fahy, J., \& Varadarajan, P. R. (2015). Sustainable competitive advantage in service industries: a conceptual model and research propositions. In Proceedings of the 1992 Academy of Marketing Science (AMS) Annual Conference (pp. 441-443). Springer, Cham.

[4] Borocki, J. (2011). Process of applying modified space model for defining company's strategy. International Journal of Industrial Engineering and Management (IJIEM), 2(2), 61-68.

[5] Carpenter, M. A., \& Fredrickson, J. W. (2001). Top management teams, global strategic posture, and the moderating role of uncertainty. Academy of Management Journal, 44(3), 533-545.

[6] Chaghooshi, A. J., Rahmani, M., \& Zarchi, M. K. (2012). Proposing a Framework for Strategic Positioning in Tile and Ceramic Industry (Integrated Approach). Journal of American Science, 8(6), 20.

[7] Cross, J., \& Henderson, S. (2003). Strategic challenges in the football business: a SPACE analysis. Strategic Change, 12(8), $409-420$.

[8] David, F. R., David, F. R., \& David, M. E. (2017). Strategic management: concepts and cases: A competitive advantage approach. Pearson.

[9] Day, G. S., \& Wensley, R. (1988). Assessing advantage: a framework for diagnosing competitive superiority. Journal of Marketing, 52(2), 1-20.

[10] FARAJIAN, M. A., MOHAMMADI, S., BIGHAM, B. S., \& SHAMS, F. Selecting Smart Strategies Based on Big Data Techniques and SPACE Matrix (FASE model). Cumhuriyet Science Journal, 40(1), 253-264.

[11] Frost, F. A. (2003). The use of strategic tools by small and medium-sized enterprises: an Australasian study. Strategic change, 12(1), 49-62.

[12] Genoveva, G., \& Siam, S. T. (2017). Analysis of marketing strategy and competitive advantage. Journal of Economic \& Management Perspectives, 11(1), 1571-1579.

[13] Gupta, M. (2015). Strategy formulation for performance improvement of Indian corrugated industry: An application of SWOT analysis and QSPM Matrix. Journal of Applied Packaging Research, 7(3), 3.

[14] Gurbuz, T. (2013). A Modified Strategic Position and Action Evaluation (SPACE) Matrix Method. In Proceedings of the International MultiConference of Engineers and Computer Scientists (Vol. 2).

[15] Liu, F. H. F., \& Hai, H. L. (2005). The voting analytic hierarchy process method for selecting the supplier. International journal of production economics, 97(3), 308-317.

[16] Michael, R., \& Pizzica Albert, J. (2015). Financial Ratios for Executives: How to Assess Company Strength, Fix Problems, and Make Better Decisions. Apress.

[17] Milohnić, I. (2012). How to Increase the Competitive Advantages of Small Hotels: Measuring the Effects of Public Relations. International journal of economic perspectives, 6(4). 
[18] Minegishi, S. (2012). Market structure and competitiveness of Credit Associations and Credit Cooperatives in Japan. International Journal of Monetary Economics and Finance, 5(3), 223-243.

[19] Paiva, E. L., Roth, A. V., \& Fensterseifer, J. E. (2008). Organizational knowledge and the manufacturing strategy process: a resource-based view analysis. Journal of Operations Management, 26(1), 115-132.

[20] Porter, M. E. (1989). From competitive advantage to corporate strategy. In Readings in strategic management (pp. 234-255). Palgrave, London.

[21] Radder, L., \& Louw, L. (1998). The SPACE matrix: A tool for calibrating competition. Long-range planning, 31(4), 549-559.

[22] Rao, A. L. (2012). Industry analysis with special reference to the Indian paper industry. International journal of business management \& research, 82-83.

[23] Rowe, J.A., Mason, O.R., Dickel, E.K., Mann, B.R., Mockler, J.R., (1994), "Strategic management - a methodological approach", 4th Edition, Addison-Wesley Publishing Company, Reading, MA.

[24] Rumanti, A. A., \& Syauta, K. J. (2013). Determining strategies based on strategic position analysis in Small and Medium Enterprises. International Journal of Information and Education Technology, 3(4), 442-447.

[25] Silaban, N., \& Syah, T. Y. R. (2018). The influence of compensation and organizational commitment on employees' turnover intention. IOSR Journal of Business and Management, 20(3), 1-6.

[26] Tellis, G. J. (1989). The impact of corporate size and strategy on competitive pricing. Strategic Management Journal, 10(6), $569-585$.

[27] Umar, Husein. 2008. Strategic Management In Action. Jakarta: PT. Gramedia Pustaka Utama.

[28] Welch, J. B. (1984). Strategic planning could improve your share price. Long Range Planning, 17(2), 144-147.

[29] https://www.bi.go.id/en/moneter/inflasi/data/Default.aspx accessed on August 4, 2020 